\title{
Divided Government: Parallel Trends in Legislative Elections
}

\author{
Anita Pritchard, Florida Atlantic University \\ Wayne Howard, Boca Raton, FL
}

This research note identified a consistent trend in legislative elections at both the national and state levels. All but nine states can be classified by two criteria-one of the parties was a majority in both the U.S. House delegation and state legislature in the 1980 s, and the same party gained seats in both legislative bodies following the 1950s. The Democratic Party gained or maintained a majority of seats in both U.S. House delegations and state legislatures in 32 states during the 30 years characterized by increases in divided government at both the national and state level. Explanations for Democratic dominance of legislatures that focus upon congressional elections only are too levelspecific.

Since 1952, Republicans have won seven of ten presidential elections, but they gained a majority in the U.S. House of Representatives only in 1952-54. Fiorina's research (1992, Ch. 3) identified an increase in divided state governments ${ }^{1}$ since 1952 , with much of the decline in unified state governments due to the disappearance of Republican legislative majorities. These findings suggest that consistent parallel trends in legislative elections underly the increase in divided government at both the national and state levels. This brief note investigates this possibility by comparing at the state level the outcomes of elections for the presidency, the U.S. House of Representatives, and state legislatures in the decade of the 1950s with comparable outcomes in the decade of the $1980 \mathrm{~s}^{2}$

Most discussions of Democratic dominance of legislative elections have concentrated upon the Congress. However, if party control of the U.S. House delegation corresponds with party control of the state legislature in the same state, then the explanations for Democratic legislative strength should recognize both national and subnational trends (Fiorina 1992, Ch. 3). For the purposes of this study, "parallel trends in legislative elections" is defined as (1) the same party has majority status in both the state legislature and U.S. House delegation in the 1980s, and (2) changes in party membership in the legislature at one level correspond with changes in legislative races at the other level-i.e., one party, then, has gained seats in both state and national legislative elections between the 1950s and 1980s.

\footnotetext{
ANITA PRITCHARD is Assistant Professor of Political Science at Florida Atlantic University. WAYNE HOWARD is a proprietor/realtor in south Florida.
} 
In order to make these evaluations, Democratic Support Scores (DSS) are calculated that represent: (1) the average proportion of U.S. House seats held by Democrats following each congressional election during each decade; (2) the average proportion of seats held by Democrats in both chambers of the state legislature during each decade. (The latter DSS is based upon the partisan distribution of seats following each presidential election, regardless of when statewide elections are held.) A third DSS, which represents the average proportion of voters for Democratic presidential candidates during each decade, is used to compare trends in legislative and presidential elections. In order to assess the direction and degree of partisan trends, change scores are calculated by subtracting the three DSS for the 1980s from the equivalent DSS for the 1950s. These scores are then used to classify states according to two criteria: (1) the majority status of political parties in the 1980s in both the U.S. House delegation and the state legislature, and (2) the direction of partisan change indicated by the change scores. For example, Alabama is classified as a "Republican Shift/Democratic State" because the change scores are all negative, i.e., more Republican legislators were elected in the 1980s than in the 1950s, and a majority of legislators-sixty-eight percent of the House delegation and ninety-two percent of state legislators-are Democrats in the 1980s (Table 1).

\section{Republican Shift/Democratic States}

The proportion of Democratic legislators declined in the states classified as Republican Shift/Democratic States; i.e., the change scores are negative (Table 1). However, the Democratic majorities in the U.S. House delegations and state legislatures were so high in the 1950s that the Democrats retained a majority, often a substantial majority, in the 1980s.

The thirteen states in this category are generally southern or border states, but they can be classified into two groups on the basis of several differences. The "Deep South" states in the first group were strongly Democratic in the $1950 \mathrm{~s}$. Democratic presidential candidates carried these states, and the DSS were at or near 1.00 for both U.S. House delegations and state legislatures. The states in the second group, which voted for Republican presidential candidates in both decades, tend to be on the periphery of the South. There is another distinction between the two groups of states. The Pearson's $r$ of .41 indicates a fairly close relationship in the "Deep South" states between partisan change in the House delegations and state legislatures, but the pattern of change for the second group is very weakly related with a Pearson's $r$ of $.07 .^{3}$ 
Table 1. Election Outcomes for the Presidency, U.S. House of Representatives, and State Legislatures for the 1950s and 1980s

\begin{tabular}{|c|c|c|c|c|c|c|c|c|c|}
\hline \multirow[b]{2}{*}{ State } & \multicolumn{3}{|c|}{ Presidential } & \multicolumn{3}{|c|}{ U.S. House of Representatives } & \multicolumn{3}{|c|}{ State Legislatures } \\
\hline & $50 \mathrm{~s}$ & $80 \mathrm{~s}$ & Change & $50 \mathrm{~s}$ & $80 \mathrm{~s}$ & Change & $50 \mathrm{~s}$ & $80 \mathrm{~s}$ & Change \\
\hline \multicolumn{10}{|c|}{ REPUBLICAN SHIFT/DEMOCRATIC STATES } \\
\hline Alabama & .63 & .43 & -.20 & 1.00 & .68 & -.32 & 1.00 & .92 & -.08 \\
\hline Arkansas & .55 & .43 & -.12 & 1.00 & .65 & -.35 & .98 & .92 & -.06 \\
\hline Georgia & 69 & .46 & -.23 & 1.00 & .86 & -.14 & .98 & .87 & -.11 \\
\hline Mississippi & .68 & .42 & -.26 & 1.00 & .68 & -.32 & 1.00 & .94 & -.06 \\
\hline North Carolina & .52 & .42 & -.10 & .92 & .72 & -.20 & .90 & .82 & -.08 \\
\hline $\begin{array}{r}\text { South Carolina } \\
\text { **Pearson's }\end{array}$ & \multicolumn{8}{|c|}{$* *$ Pearson's $\mathrm{r}=.41$} & -.18 \\
\hline Florida & .44 & .38 & -.06 & .90 & .66 & -.24 & .95 & .68 & -.27 \\
\hline Kentucky & .48 & .44 & -.04 & .78 & .57 & -.21 & .75 & .76 & +.01 \\
\hline Louisiana & .46 & .44 & -.02 & 1.00 & .68 & -.21 & 1.00 & .90 & -.10 \\
\hline Missouri & .50 & .44 & -.06 & .82 & .60 & -.22 & .60 & .68 & +.08 \\
\hline Oklahoma & .45 & .36 & -.09 & .76 & .76 & .00 & .83 & .73 & -.10 \\
\hline Tennessee & .48 & .44 & -.04 & .78 & .68 & -.10 & .80 & .62 & -.18 \\
\hline Texas & .46 & .40 & -.06 & .96 & .70 & -.26 & 1.00 & .76 & -.24 \\
\hline \multicolumn{10}{|c|}{$* *$ Pearson's $\mathrm{r}=.07$} \\
\hline California & .43 & .44 & +.01 & .42 & .59 & +.17 & .40 & .59 & +.19 \\
\hline Connecticut & .40 & .43 & +.03 & .30 & .56 & +.26 & .16 & .63 & +.47 \\
\hline Delaware & .46 & .44 & -.02 & .50 & .80 & +.30 & .54 & .54 & .00 \\
\hline Illinois & .42 & .46 & +.04 & .45 & .55 & +.10 & .42 & .54 & +.12 \\
\hline
\end{tabular}


Table 1 (continued)

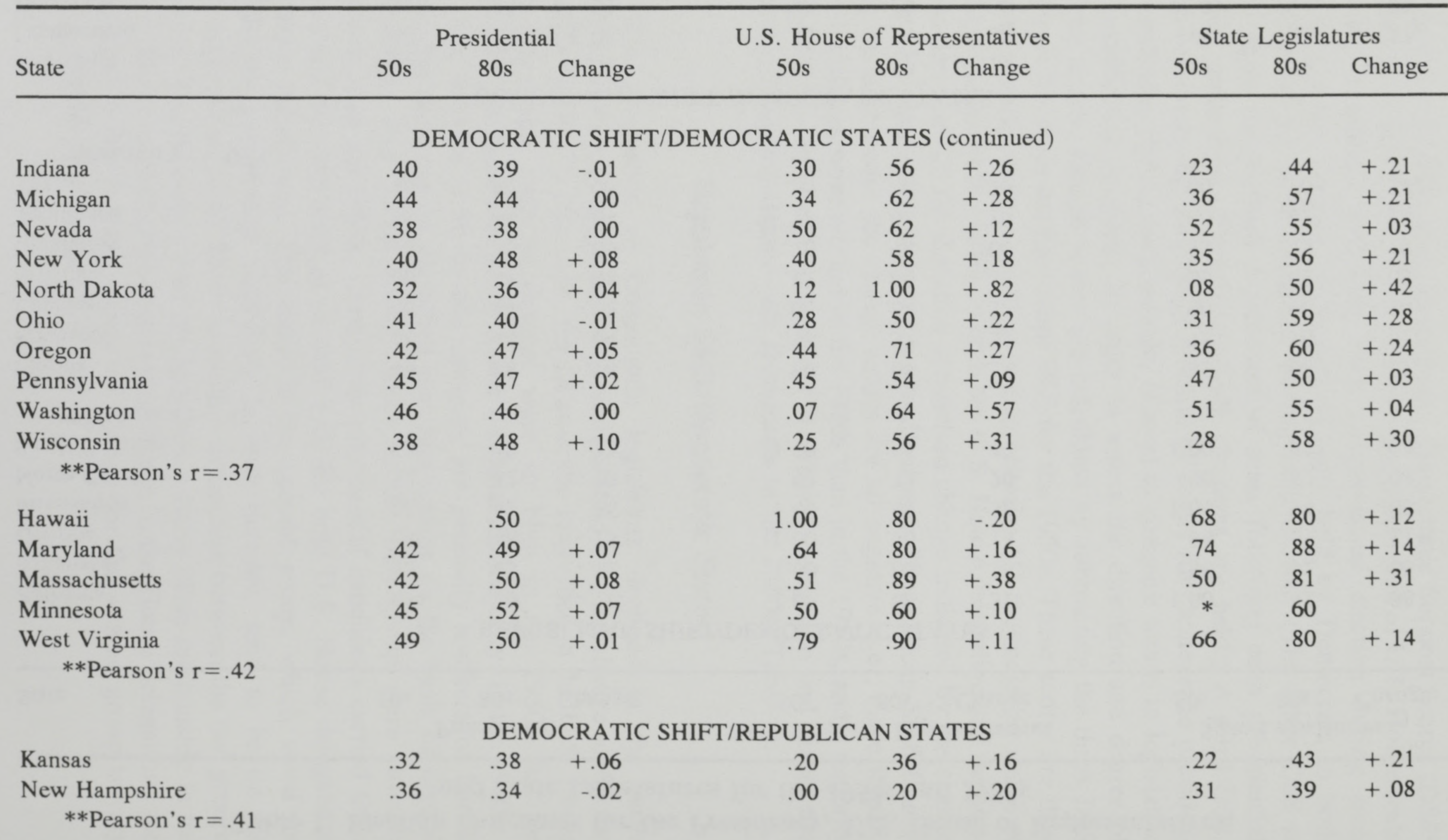


Arizona

Colorado

Idaho

$* *$ Pearson's $\mathrm{r}=.45$

Nebraska

Utah

Vermont

Wyoming

$* *$ Pearson's $\mathrm{r}=-.96$

\section{REPUBLICAN SHIFT/REPUBLICAN STATES}

$\begin{array}{lll}40 & .34 \quad-.06\end{array}$

$\begin{array}{lll}.40 & .39 & -.01\end{array}$

$\begin{array}{lll}36 & .30 \quad-.06\end{array}$

.50

$\begin{array}{ll}.33 & -.17\end{array}$

$\begin{array}{lll}.71 & .37 & -.34\end{array}$

$\begin{array}{lll}.46 & .38 & -.08\end{array}$

$\begin{array}{lll}.44 & .31 & -.13\end{array}$

$\begin{array}{lll}.50 & .30 \quad-.20\end{array}$

$\begin{array}{rrr}.12 & .06 & -.06 \\ .12 & .14 & +.02 \\ .25 & .00 & -.25 \\ .00 & .00 & .00\end{array}$

$\begin{array}{rrr}* & * & \\ .38 & .28 & -.10 \\ .14 & .46 & +.32 \\ .32 & .36 & +.04\end{array}$

\section{MIXED STATES}

Alaska
Iowa
Maine
Montana
New Mexico
New Jersey
Rhode Island
South Dakota
Virginia

$\begin{array}{rrr}.34 & .60 & .00 \\ .38 & .48 & +.10 \\ .32 & .44 & +.12 \\ .43 & .40 & -.03 \\ .43 & .42 & -.01 \\ .38 & .38 & .00 \\ .46 & .53 & +.08 \\ .36 & .40 & +.04 \\ .40 & .40 & .00\end{array}$

$* *$ Pearson's $\mathrm{r}=.53$

*Elected without party designation

**Pearson's correlation coefficient for Change Scores-U.S. House of Representatives and Change Scores-State Legislatures.

$\begin{array}{rrrrrr}-.60 & .64 & .54 & -.10 & & \\ .16 & .40 & +.24 & .16 & .56 & +.40 \\ .30 & .20 & -.10 & .23 & .56 & +.33 \\ .75 & .50 & -.25 & .47 & .50 & +.03 \\ 1.00 & .36 & -.64 & .68 & .62 & -.06 \\ .36 & .58 & +.22 & .30 & .37 & +.07 \\ 1.00 & .40 & -.60 & .62 & .80 & +.18 \\ .25 & .83 & +.58 & .12 & .28 & +.16 \\ .78 & .38 & -.40 & .94 & .72 & -.22\end{array}$




\section{Democratic Shift/Democratic States}

In fourteen states the Democrats moved from minority or near-minority to majority status in both the U.S. House delegations and state legislatures in the 1980s (Pearson's $r$ for change scores $=.37$ ). However, the Democratic majority is not overwhelming; the proportion of Democratic legislators generally ranges from .50 to .60 . Democratic presidential candidates did not gain a majority vote during either decade, but the proportion of acquired votes was stable. Compared to the other categories where the DSS for presidential elections generally declined, Democratic presidential candidates were relatively successful. The states in this category are varied, but they include the three states on the West Coast, several states clustered around the Great Lakes, and some northeastern states.

Five states were consistently Democratic. There were Democratic majorities in both the House delegations and state legislatures in both decades, and Democratic presidential candidates carried, or nearly carried, these states in the 1980s. Further, the DSS were generally positive, indicating that the Democratic majorities increased over the decades to generally substantial majorities in the $1980 \mathrm{~s}(\mathrm{r}=.42)$.

\section{Democratic Shift/Republican States}

The Democrats gained legislative seats in two Republican States, Kansas and New Hampshire. However, the Republican party maintained a substantial majority in both the U.S. House and state legislature during both decades.

\section{Republican Shift/Republican States}

The Republican party moved from minority to majority satus in both legislatures in only three states-Arizona, Colorado, and Idaho. The change scores in the remaining four states were mixed $(r=-.96)$, but the party maintained a clear and generally substantial majority in all of these states. Republican presidential candidates easily carried the "Republican states" in both decades.

With the exception of Vermont and New Hampshire, the Republican states are mountain and western states. They generally are rural, thinlypopulated states which have not been characterized by a high degree of change in either population or the economy. 


\section{Mixed States}

Nine states are classified as "mixed" because they have a Democratic majority in only one category. However, in six of the states the change scores are either consistently negative or positive, which indicates a consistent movement toward one of the parties $(r=.53)$.

\section{Discussion}

A consistent trend in legislative elections underlies divided government at both the national and state levels. All but nine states can be classified by two criteria: one of the parties had a majority in both the U.S. House delegation and the state legislature in the 1980s, and the change scores were in the same direction for both sets of elections-i.e, the same party had gained seats in both legislative bodies since the 1950s. The party with a majority in both houses of the state legislature nearly always has a majority in the U.S. House delegation.

The Democratic party gained or maintained a majority of seats in both U.S. House delegations and state legislatures in 32 states during the 30 years characterized by increases in divided government at both the national and state level. In part, the Democratic party was strong in the 1980s because decline generally occurred in Southern states where their majorities were large in the 1950s, and therefore easy to maintain. Even if Southern states are removed from the analysis, however, Democrats still had majority status in 19 states, and they gained legislative control in 14 states. Several of these were heavily populated states with large House delegations. The Republican decline in legislatures was remarkable; they maintained majority status in only 9 states, most of which were small and thinly populated.

Clearly, explanations for Democratic legislative strength that focus only upon Congress are too level-specific. Democratic majorities in the U.S. House parallel Democratic majorities in state legislatures, and both increased over a 30-year period. While research on congressional elections has shown that structural factors such as gerrymandering, campaign finance laws, and incumbency (Jacobson 1990; Fiorina 1992) are not responsible for Democratic majorities in Congress, these conclusions have not been tested in state legislative elections. There also is some agreement that Republicans have fielded weaker congressional candidates (Jacobson 1990; Fiorina 1992), but the possibility of weaker Republican candidates for state legislatures has not been investigated. Obviously, electoral forces may be responsible for the gains in Democratic legislative strength at both levels of government. However, since the research reports aggregate level outcomes, explanations 
for electoral forces need to incorporate individual-level partisanship into models of aggregate change such as the work by MacKuen, Erikson and Stimson (1989). In any case, the circumstances that create Democratic legislative majorities do not appear to be accidental or random.

\section{NOTES}

${ }^{1}$ Divided government generally is defined as existing when the executive and both houses of the legislature are not controlled by the same party (see, e.g., Fiorina 1992).

${ }^{2}$ The analysis relies primarily upon those elections which provide the largest possible $\mathrm{N}$ in each state-U.S. House and state legislative races. Therefore, U.S. Senate and gubernatorial elections are not included. The presidential elections are included for comparative purposes, but the major measurements are the elections with larger Ns.

${ }^{3}$ The political changes in the South have been studied in depth (see Black and Black 1987).

\section{REFERENCES}

Black, Earl and Merle Black. 1987. Politics and Society in the South. Cambridge: Harvard University Press.

Fiorina, Morris. 1992. Divided Government. NewYork: MacMillan.

Jacobson, Gary C. 1990. The Electoral Origins of Divided Government. San Francisco: Westview Press.

MacKuen, Michael B., Robert S. Erikson, and James A. Stimson. 1989. Macropartisanship. American Political Science Review 83: 1125-42.

Wattenberg, Martin P. 1991. The Rise of Candidate-Centered Politics. Cambridge: Harvard University Press. 